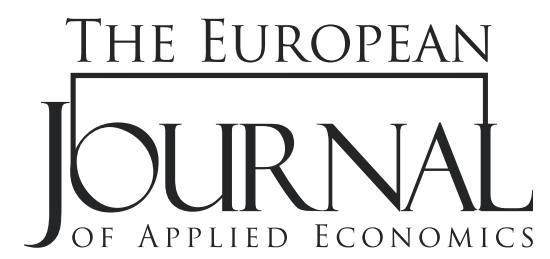

EJAE 2021, 18(1): 15 - 38

ISSN 2406-2588

UDK: $338.23: 336.74$

005.334:336.71(292.63/.69)"2001/2015"

DOI: 10.5937/EJAE18-28152

Original paper/Originalni naučni rad

\title{
MONETARY POLICY AND BANK RISK-TAKING IN SUB-SAHARA AFRICA
}

\author{
Gabriel Aboyadana* \\ Department of Economics, \\ Strathclyde Business School, \\ Glasgow, Scotland, \\ United Kingdom
}

Article info:

Received: September 3, 2020

Correction: October 19, 2020

Accepted: November 2, 2020

\section{Keywords:}

Risk-taking,

Financial Crisis, Monetary Policy, Africa.

\section{JEL Classification:}

E52, E58, G01, G18, G21, G28, G31

\section{INTRODUCTION}

The discussion about the risk-taking channel of monetary policy can be traced to the 2008 global financial crisis. That crisis proved that even the most advanced financial systems are vulnerable to uncertainties, which can lead to failures both for the domestic financial system and international financial markets and could have detrimental consequences on the real economy. The crisis was sparked by excessive credit expansion and the burst of a chain of bubbles in the real estate market (Özşuca \& Akbostanci, 2016). These events led to instability in the global credit market which led to a realisation of an existing threat to the stability of the global financial market.

Policymakers and researchers alike have systematically raised questions about the possible causes of the crisis to explain the factors that are responsible for the fragility of the global financial system. In the meantime, however, though empirical research in this regard is scant, there appears to be a consensus on some factors that could have caused the crisis. These include failure of macroprudential policies, regulatory and supervisory failure, the emergence of complex financial instruments and weak corporate governance systems (Bruno, Shim, \& Shin, 2017; Fahr \& Fell, 2017). 
In addition to these, monetary authorities have also been blamed for implementing excessively accommodative monetary policies in the half-decade before the crisis (Dell'Ariccia, Laeven, \& Marquez, 2014). This has sparked a strong debate among economists because those who point fingers at monetary policy have argued that when the monetary condition is lax such as in a period of low-interest rates and loose liquidity over prolonged periods, there is an increased incentive for financial intermediaries to take more risk. Thus, the proponents on this side of the debate hold the view that monetary policy was an important driving tool that caused the financial crisis. The situation becomes even more contentious when we consider that, to remedy the effects of the crisis, monetary authorities in some countries eased the monetary condition further. Consequently, the debate over the relationship between monetary policy and financial stability has intensified among researchers and in policy discourse.

Before the financial crisis, monetary policy paid little attention to financial stability because traditionally the role of monetary policy has been thought of in terms of price stability whereas macroprudential policies were the responsibility of supervisory authorities. Moreover, the rapid innovation in the financial sector has been regarded as a tool for achieving stability in the financial system. That notwithstanding, the crisis has given strong basis to argue that policy decisions aimed at financial stability can no longer be taken without recourse to the effect of monetary policy (Bruno et al., 2017; Salle \& Seppecher, 2018). As well, monetary policy decisions must consider implications for financial stability.

The question of how monetary policy transmits to banks' risk-taking incentives has been central in the said debate and has led to the emergence of the so-called risk-taking channel. Risk-taking channel refers to the perception and the pricing of risk because of the monetary policy stance at a given time. The emphasis has been on how policy stance affects the risk appetite and the risk perception of banks. The central argument here is that when interest rates are very low banks will lean towards higher risk-taking and cause a shift in credit supply; that is, the risk-taking channel implies an increase in the riskiness of lending via low-quality portfolios. In this way, monetary policy can contribute to financial instability via a build-up of imbalances in the financial system. The mechanism through which monetary policy can affect bank risk can be complex and dynamic. A few ways are identified. Firstly, it can affect the valuation of their incomes and cash flows, and this affects how they measure risks. Secondly, lowinterest rates could make banks aggressive, to meet profit targets. Thirdly, the risk-taking channel can operate through how policies are announced and the reaction function of the monetary policy authority including the effect produced by the idea that the reaction function of the monetary policymaker is effective in curtailing excessive downside risk.

While the debate has been based on the prolonged period of low-interest rates in the US and EU in the five years preceding the crisis, it is important to admit that that argument only loosely relates to the situation in sub-Sahara Africa. Interest rates have not been low in Africa both in absolute terms and when compared to rates in the US and EU for any period in the past but since the end of the global financial crisis, interest rates in many sub-Sahara African countries have demonstrated a tendency to decline (see Fig. 1). That notwithstanding, there is a justification for studying the risk-taking channel of monetary policy in the context of Africa, especially if we consider context-specific conditions and dynamics. To begin with, while interest rates have not fallen so low as in the case of the US and EU, they have fallen to historically low levels in many countries in the years after the crisis, particularly for countries that are part of common currency areas. Moreover, the business community continues to advocate for even lower interest rates so that cost of credit can fall and boost real investments. 
Also, African countries are bank-oriented and coupled with the prevailing policy environment in many countries provides us with an ideal setting for analysing this transmission channel of monetary policy. Consequently, our focus in this study is to empirically determine the relationship between monetary policy and risk-taking of banks operating in 37 countries in sub-Sahara Africa, using data from 2001 to 2015 and for different types of risk. We also determine the impact of size and capitalisation in moderating banks' risk-taking behaviour. The results show evidence of the existence of a risktaking channel of monetary policy in the context of sub-Sahara Africa when assessed using different risk measures. The impact of monetary policy on bank risk-taking in sub-Sahara Africa has yet to be examined in the literature. We introduce a novelty in risk-taking literature for Africa by using a large cross-country panel consisting of only Africa countries. Additionally, this study highlights bank-specific characteristics that may have an impact on risk-taking.

The rest of the paper is organised as follows. Section 2 reviews the risk-taking literature. Section 3 describes the data and methods employed. Section 4 reports and discusses the results. Section 5 concludes.

\section{LITERATURE REVIEW}

\section{Banking Sector Risk}

The strength or weakness of a banking industry is a function of how much risks it is exposed to. Laeven \& Valencia (2013) observed that there have been 147 banking crises across the world from 1970 to 2011 and this was accompanied by 218 currency crises. They observed that those crises often occurred in one country and then spread to other countries due to increasing integration of the global financial system. Cihák \& Schaeck (2010) agreed with this observation and affirmed that those crises are difficult to predict. Laeven \& Valencia's (2013) report also revealed that many of the factors that led to most banking crises were within the control of bank management and were due to internal policies and decisions. Industry players have therefore tended to focus more attention on the management of uncertainties that the sector is prone to. Consequently, risk and risk management have become topical in the banking literature. This has particularly been the case following the global financial crisis that started in 2008.

One is likely to conclude that given the structural deficiency of Africa's economy, there is an enormous risk in the banking industry. There is the need however, to obtain an empirical basis for the sources and nature of the factors that put the financial system at risk and how the sector responds to these factors over time. This is because the risk in the banking industry has proven to be crucial for the overall financial health of any economy (Alter \& Schüler, 2012). At least this is evident from the impact of banking crisis in the US, Europe and Asia (Black, Correa, Huang, \& Zhou, 2016; Carbó-Valverde, Benink, Berglund, \& Wihlborg, 2015).

Government intervenes in the economy from time to time to achieve some macroeconomic objective. One of the tools of intervention has been the monetary policy stance. Loose monetary policy can impact bank risk-taking in many ways such as the valuation of bank assets (Altunbas, Gambacorta, \& Marques-Ibanez, 2010). In terms of valuation, lower interest rates increase the value of assets, incomes and collateral and may cause banks to modify their estimation of risk downward, thus increasing their risk appetite. Our focus in this study is to determine the impact of monetary policy on bank risk-taking in sub-Sahara Africa. 


\section{Theories}

\section{Moral Hazard Theory}

The moral hazard theory is commonly cited to explain bank risk-taking behaviour. The theory emphasises asymmetric information and deposit insurance shielding banks from the control of depositors (Jokipii \& Milne, 2011; Rahman, Zheng, \& Ashraf, 2015). Empirical studies have shown that capital adequacy regulation may reduce the number of risky assets that are held by banks (Zheng, $\mathrm{Xu}, \&$ Liang, 2012). They also show that if we assume a utility function for a risk adverse bank, their portfolio composition may be distorted towards more risky assets (Hamza \& Saadaoui, 2013; Mensah, 2013). As a result, average risk can increase and the bank may require risk consistent weights to adjust for moral hazard (Zheng et al., 2012).

\section{Franchise Value Theory}

The franchise value (or charter value) theory explains bank risk-taking in a framework of franchise value. Franchise value can be defined as how much of the value of the bank would be foregone should the bank be closed (Chen, Hwang, \& Liu, 2012). Factors that may increase franchise value include regulatory restrictions on entry and competition in the industry. It argues that since shareholders would lose big in case of closure, banks with higher franchise value would have lower incentives to take higher risk. Even though traditional theory suggests that high franchise value reduces bank risk-taking incentives, the recent financial crisis saw banks with exceptionally highly valuable franchises getting exposed.

\section{A Monetary Policy Transmission Channel}

There are two ways that monetary policy can primarily affect bank risk-taking. Firstly, it affects the valuations, incomes and cash flows of banks and this impacts on how they measure risks. A low-interest rate will bloat the value of their assets and increase their valuation, thus increasing their risk appetite (Altunbas, Gambacorta, \& Marques-Ibanez, 2014). Low-interest rates could make banks aggressive in an attempt to meet profit targets (Altunbas, Gambacorta, \& Marques-Ibanez, 2012; de Moraes, Montes, \& Antunes, 2016). Given the positive relationship between risk and return, they will take on more risk to meet their set nominal targets (Altunbas et al., 2012).

Banks are thought to take on more risk in a lax monetary policy environment. This means that while monetary policy authorities seek to achieve desirable macroeconomic ends using lax monetary policy measures, this can trigger bank failures as a result of excessive risk-taking by banks and defeat the intended purpose of the policy (Bekaert, Hoerova, \& Lo Duca, 2013). What we do not know is how long this process takes. For example, Jiménez, Ongena, Peydro, \& Saurina (2014) and Ioannidou et al. (2015) find evidence that in Spain and Bolivia, a "too accommodative" monetary policy led to additional risk-taking by banks before the global financial crisis in 2008. We know that before the crisis several countries were in recessions and monetary authorities used the traditional method of expansionary monetary policies to stimulate investment and to help their economies recover. Similar to the findings of Jiménez et al., (2014) and Ioannidou et al. (2015), Altunbas, Gambacorta, \& Marques-Ibanez (2010) and Maddaloni \& Peydró (2011) find supportive evidence of the risk-taking channel of monetary policy using cross-country data. 


\section{EMPIRICAL STRATEGY}

\section{Econometric Specification}

$$
\begin{aligned}
\text { Risk - Talking }_{\mathrm{it}} & =\delta_{1} \text { MonetaryPolicy }_{\mathrm{t}}+\delta_{\mathrm{j}} \sum_{\mathrm{j}=1}^{2} \text { BankCharacteristics }_{\mathrm{it}} \\
& +\delta_{\mathrm{i}} \sum_{\mathrm{j}=1}^{\mathrm{T}} \text { Macroeconomic Variables }_{\mathrm{t}}+\omega_{\mathrm{i}}+\mu_{\mathrm{t}} \varepsilon_{\mathrm{it}}
\end{aligned}
$$

Where $t$ refers to the index for time $(1 \ldots \ldots . . \mathrm{T})$, the year and $\mathrm{i}$ is the index for the individual bank $(1 \ldots \ldots . N)$ and $\mu, \omega$ and $\varepsilon$ are the error terms and $j=1, \ldots \ldots .$.

\section{Estimation}

The LSDV estimator is pooled OLS including a set of N-1 dummy variables which identify the heterogeneity within each panel and hence an additional N-1 parameter. Due to the constant that is included, one of the individual dummies is dropped. The use of Least Squares Dummy Variable Model helps to obtain the bank specific effects which absorb omitted variables that differ from one bank to another but are constant over time. The LSDV estimates are optimal if the error processes have the same variance (homoscedasticity requirement) and the errors are independent of each other (no autocorrelation requirement). We examined the data for homoscedasticity and autocorrelation and found that most of the specifications had heteroscedastic and autocorrelated error terms. It is however common to find panel processes being plagued by complex error correction issues and so we report robust standard errors instead of the standard OLS errors following a similar approach to Ofoeda et al. (2012). This ensures that the LSDV estimates are optimal. For robustness still, a panel corrected standard error (PCSE) technique was implemented. The PCSE corrects for heteroscedasticity and autocorrelation. The two techniques use different error correction processes to achieve similar outcomes. The LSDV with robust standard error implements the white-correction whiles PCSE.

\section{Measuring Risk-Taking}

\section{- Non-Performing Loans Ratio (NPLR)}

The non-performing loans ratio is a measure that shows the stock of loans that are non-performing compared to total loan stock at a given point in time (Angkinand \& Wihlborg, 2010). We estimate the model using NPLR (expressed as a percentage) as a measure of credit risk-taking (Shahid, Haque, \& Shahid, 2016). We transform this variable by taking logs as follows:

$$
\ln N P L R=\ln \left(\frac{\text { Non }- \text { Performing loans }}{\text { Total Loans }} * 100 \%\right)
$$

Higher values of lnNPLR denote higher credit risk while lower values indicate lower credit risk. 


\section{- Loan Loss Provision to Gross Loans Ratio (LLP)}

Asset risk refers to uncertainties in the realisation of the assets. A high risk means that there is a greater uncertainty on whether a bank would be able to realise its assets. We measure asset risk using the ratio of loan loss reserve to gross loans (expressed as a percentage) (Distinguin, Roulet, \& Tarazi, 2013; Sarkar \& Sensarma, 2016). Loans are an important part of bank assets and can be large relative to other asset classes. Banks therefore use the loan balance as a basis for making a provision for potential losses to assets. Banks keep the reserve in anticipation of shocks to asset value. The reserve is itself recorded as an asset in the balance sheet of the firm and it reflects movements in the assets of the bank and asset quality. A high reserve helps banks to absorb losses better and this makes banks with a higher reserve less prone to bankruptcy. A higher ratio is desirable, however, to present the result consistently, we take the inverse by multiplying it by minus 1 . This measure is stated formally as:

$$
\text { LLP }=\frac{\text { Loans Loss Provision }}{\text { Total Assets }} * 100 \%
$$

\section{Other Variables}

Monetary Policy: For this study, we consider the monetary policy rate as a desirable measure for monetary policy (Fiador \& Biekpe, 2015; Matemilola, Bany-Ariffin, \& Muhtar, 2015). The monetary policy rate is an explicit statement by the monetary authorities. It signals interest rates in the economysomething that directly affects bank performance.

Bank Size: Bank size has been found to influence bank risk-taking across time and contexts (GarcíaKuhnert, Marchica, \& Mura, 2013; Laeven, Ratnovski, \& Tong, 2016; Rahman et al., 2015; Terraza, 2015). We use the natural log of total assets following Bhagat, Bolton, \& Lu (2015), Ioannidou et al. (2015) and Stolz \& Wedow (2011) as a proxy for bank size. This has the advantage of reducing the possibility of heteroscedasticity and to pull in extreme values (García-Kuhnert et al., 2013).

Profitability: We proxy profitability by ROA since this is readily obtainable and is the preferred measure of profitability in the literature (Dong, Firth, Hou, \& Yang, 2016; Kolapo, Ayeni, \& Oke, 2012).

Competition: We follow Sarkar \& Sensarma (2016) and Delis \& Kouretas (2011) to measure competition using the Concentration Ratio (CR) in the banking industry. The Concentration Ratio measures how much of total industry assets are owned by a selected number of big banks. It measures industry dominance. We use the ratio of assets owned by the three largest banks (known as CR3). A high ratio signifies low competition because it means that few banks control a significant portion of the industry; they have market power. It is expected that high competition will lead banks to take more risks in a bid to remain competitive in the market.

Cost Efficiency: Cost efficiency is measured by the ratio of expense to revenue or cost to income (expressed as a percentage). It tells us how many dollars it costs to generate a dollar in revenue. A high ratio signals low efficiency and this is expected to reduce profit and increase risk (Kar, 2012; Zaini Abd Karim, Chan, \& Hassan, 2010). It is plausible to expect that banks that are cost efficient are likely to be taking less risk. 
Financial Openness: Financial openness has been used to explain bank risk-taking in previous studies (Luo, Tanna, \& De Vita, 2016). It indicates the level of regulation in the financial system of a country. We measure financial openness with the KAOPEN Index developed by Chinn \& Ito (2006).

\section{RESULTS AND DISCUSSION}

\section{Summary Statistics}

Table 2 shows the descriptive statistics for all the variables used in the study. The table presents information on the number of observations, the mean and standard deviation, and the minimum and maximum values for each variable. This allows us to see the upper and lower bounds of each variable in the dataset as well as the averages and dispersion of the variables. For brevity, only a few variables are discussed. The study included 534 banking organisations listed in the BankScope database from 37 countries in Sub-Sahara Africa for a period of 15 years starting from 2001 to 2015. The data is unbalanced and contains gaps. The table also shows that the data on some variables were unavailable for some banks and countries in some years and this accounted for some variables having fewer observations this also shows in the regression tables. Similar to Kuranchie-pong, Bokpin, \& Andoh, (2016) and Pathan, (2009) we observe that some of the variables such as policy rate and cost efficiency recorded outliers. To deal with the extreme values, some variables were winsorized and others were log-transformed. We present additional descriptive statistics for variables that were winsorized or log transformed.

The mean (standard deviation) of Competition is 69.73 (18.97) which shows that most banking sectors in Africa are weakly competitive. Indeed, we find support for this conclusion in the data. The data shows that many of the countries in the sample have had concentration ratios (CR3) above 50\% for most of the sample period. Another observation is that, except for a few countries like Nigeria and Ghana whose banking sector became more competitive over time, many others were becoming less competitive. This could be explained partly because of regulatory factors which led to bank mergers and acquisitions over the period. The mean (standard deviation) of bank assets is USD1,210,417 (USD $6,578,848)$. This shows that there is significant heterogeneity between banks in terms of size as can be seen from the minimum and maximum value.

The mean (standard deviation) of monetary policy rate was $10.81 \%(7.435 \%)$. This shows that the average country in the sample had tight monetary policy regimes compared with rates in more developed economies. High policy rates are used to control inflationary tendencies and signal the cost of loanable funds. Fiador (2015) reported that during the period of this study many countries in Africa had high inflation rates. This is shown by the range and mean of the inflation. This could explain why the policy rates were high as found.

\section{Correlation Analysis}

Correlation coefficients of variables are reported in Table 3. Coefficients that are significant at 10\% are reported with a star. Monetary policy shows a negative and significant correlation with the solvency risk, liquidity risk and capital risk. We interpret the sign of the correlation coefficient to mean that expansionary policy rates are associated with high risk-taking in terms of default, liquidity, and capital risk. This strengthens the conclusions of the regression results discussed below. 


\section{Model Diagnostics}

\section{No Multicollinearity}

The results in table 3 show that no pair of variables have a correlation coefficient greater than 0.5 and so there is no multicollinearity in our data. Thus, the models specified do not suffer from multicollinearity. This implies that the standard errors of the model estimates are not inflated and are not biased.

\section{Homoscedasticity}

This assumption is required to ensure that the LSDV estimators are efficient, unbiased, and consistent. If this assumption is violated, the model is said to be heteroscedastic, that is, the error processes are not stationary. We perform this test using the Breusch-Pagan / Cook-Weisberg test for heteroscedasticity. The results of the test are shown in table 4 . The results show that, at $10 \%$ significance level, all the model specifications are heteroscedastic. Even though models are still unbiased and consistent in the presence of heteroscedasticity, they are no longer efficient. We remedied this by reporting robust standard errors.

\section{No Autocorrelation}

We test for first order autocorrelation using the Wooldridge test for autocorrelation. The results are presented in table 5. If the assumption of no autocorrelation is violated, LSDV estimators are still unbiased but are not efficient. The results show that there is first order autocorrelation. To correct for this violation, we report robust standard errors.

\section{Exogeneity}

Exogeneity is a required condition for optimal LSDV estimates. The exogeneity condition requires that no explanatory variable be correlated with a corresponding error. If this condition does not hold, then there is said to be endogeneity within the model. Based on economic theory, we expected that monetary policy rate will be endogenous. To establish this, we conducted the test of endogeneity by using the Durbin and Wu-Hausman tests for endogeneity. The results are presented in table 6 . The results of the tests in table 6 show that all models are exogenous.

\section{Regression Results}

\section{Monetary Policy and Risk-taking}

Table 7 reports the empirical results of the relationship between monetary policy and risk-taking among banks in sub-Sahara Africa. In each column, a positive coefficient shows that monetary policy rate moves in the same direction as risk-taking and a negative coefficient shows otherwise. We present results for the LSDV regression and the PCSE regression. Our discussion is based on the LSDV results for brevity because the findings are qualitatively similar across techniques. 
We find that the relationship between monetary policy and credit risk-taking is positive and significant. A $1 \%$ increase in monetary policy rate will increase banks' credit risk by $0.5726 \%$. Put differently, if monetary policy rates double from their current average to about $22 \%$, banks' credit risks (in this case non-performing loans ratio) will increase by about $60 \%$. This means that in periods of high monetary policy rates, there is an increase in non-performing loans, hence high credit risk. We explain this in two ways. Firstly, high interest rates lead to high borrower default because of increased cost of borrowing. This directly increases the NPLR. Secondly, because high interest rates signal high borrower solvency risks, risk-averse banks will reduce lending. As the denominator decreases, the NPLR is increased. At least one of these must occur for credit risk to increase or both may occur but at different magnitudes. From the perspective of the borrower, as interest rates increase (particularly for floating rates); they tend to be unable, or less likely to meet their loan obligation.

This is consistent with Forssbæck (2011), Tabak et al., (2014), Adhikari \& Agrawal (2014) and Agoraki, Delis, \& Pasiouras, (2011). Forssbæck (2011) used NPLR and inverse Z-Score as proxies for risk-taking and their work included real interest rate- a proxy of monetary policy measure- and found similar results. The coefficients of monetary policy rate are smaller for solvency risk than for credit risk suggesting that in periods of rising policy rates, credit risk increases faster than the rate at which solvency risk increases in periods of falling policy rates. Thus, as policy rates increases, banks' credit risk rises faster than the rate at which their solvency risk declines.

It can be shown that the signs of the results for solvency risk and credit risk and our interpretation are logically consistent. To see this, assume that as we explained in the case of the latter, there will be fewer borrower defaults when policy rates are lower. On the other hand, we explained in the case of the former that in a period of low policy rate banks will be more aggressive to meet targeted nominal returns; undertaking more income generating activities such as giving out more loans ${ }^{1}$. As they do these, the denominator of the NPL ratio become bigger hence having less credit risk. Thus, solvency risk and credit risk will move in opposite directions for any given change in the monetary policy rates.

\section{Asset Risk}

The results show that when monetary policy rate is reduced by $1 \%$, asset risk rises by $1.37 \%$. This can be explained by similar factors as in solvency risk. As monetary policy rates decline, the value of banks assets will increase and so any adverse event will impact more on banks. In orderto create a buffer against this uncertainty, banks will keep higher loan loss reserves.

\section{The Effect of Bank Size and Profitability}

We investigate the effect of size and profitability in the monetary policy channel. The result suggests that the impact of monetary policy rate on bank risk is diminished for bigger banks, for solvency risk, liquidity risk, asset risk and capital risk but amplified for credit risk. This finding is partly consistent with Delis \& Kouretas (2011) who found that in the euro area interest rates impacted the risk of bigger banks less than smaller banks. In the case of Delis \& Kouretas (2011) they examined asset and credit risks only.

1 Holding all of our arguments in the case of solvency risk 
For profitability, the result show that the risks of more profitable banks were impacted less by monetary policy for all types of risks except capital risk. For capital risk, more profitable banks were impacted more by the monetary policy rate. These relationships were however only statistically significant for asset risk and capital risk.

\section{CONCLUSION AND POLICY RECOMMENDATION}

This paper contributes to the bank risk-taking literature by providing evidence of a relationship between monetary policy and risk-taking in developing countries. Banking researchers have always known that high risk-taking was a threat to banks. However, little attention was paid to the potential for macroeconomic policy to affect banks' risk appetite before the 2008 financial crisis. The results of this study have shown that a lax monetary policy regime is associated with increases in banks' risk-taking behaviour. This holds for different risk types.

The results show that low monetary policy rates cause banks to take more risk. Secondly, changes in monetary policy influence changes in risk-taking behaviour. Banks form expectations of monetary policy stance and revise their risk appetite accordingly. Also, bank characteristics such as size and capitalisation are important in moderating the effect of monetary policy on bank risk-taking. Bigger banks and well-capitalised banks take more risk on average. Thus, there is an insulation effect for size and capitalization. Industry characteristics are important in moderating the effect of monetary policy on bank risks. Banks in competitive national sectors are insulated from the adverse effects. A strong domestic currency was found to influence higher risk-taking by banks. All our results were robust to the type of risk-taking measure. In the case of credit risk, it was shown that adjusting for bank and industry characteristics were crucial in arriving at our conclusion. These results confirm findings by previous authors who studied banks in other countries. We, therefore, show that banks in Africa are not different in their response to monetary policy. The policy implication of our results is that central banks should be modest in easing the monetary condition.

We recommend that central banks in Africa should slow down their pace of monetary policy expansion. Even though it is a good intention to ease monetary conditions to reduce the cost of borrowing and grow the economy, this could threaten the stability of the financial system. Such an intention should be carried out gradually over a long time. 


\section{REFERENCES}

Adhikari, B. K., \& Agrawal, A. (2016). Does local religiosity matter for bank risk-taking? Journal of Corporate Finance, 38, 272-293. https://doi.org/10.1016/j.jcorpfin.2016.01.009

Agoraki M. E. K., Delis, M. D., \& Pasiouras, F. (2011). Regulations, competition and bank risk-taking in transition countries. Journal of Financial Stability, 7(1), 38-48. https://doi.org/10.1016/j.jfs.2009.08.002

Alter, A., \& Schüler, Y. S. (2012). Credit spread interdependencies of European states and banks during the financial crisis. Journal of Banking and Finance, 36(12), 3444-3468. https://doi.org/10.1016/j.jbankfin.2012.08.002

Altunbas, Y., Gambacorta, L., \& Marques-Ibanez, D. (2010). Bank risk and monetary policy. Journal of Financial Stability, 6(3), 121-129. https://doi.org/10.1016/j.jfs.2009.07.001

Altunbas, Y., Gambacorta, L., \& Marques-Ibanez, D. (2012). Do bank characteristics influence the effect of monetary policy on bank risk? Economics Letters, 117(1), 220-222. https://doi.org/10.1016/j.econlet.2012.04.106

Altunbas, Y., Gambacorta, L., \& Marques-Ibanez, D. (2014). Does monetary policy affect bank risk? International Journal of Central Banking, 10(1), 95-135. https://ijcb.org/journal/ijcb14q1a3.pdf

Angkinand, A., \& Wihlborg, C. (2010). Deposit insurance coverage, ownership, and banks' risk-taking in emerging markets. Journal of International Money and Finance, 29(2), 252-274. https://doi.org/10.1016/j.jimonfin.2009.08.001

Bekaert, G., Hoerova, M., \& Lo Duca, M. (2013). Risk, uncertainty and monetary policy. Journal of Monetary Economics, 60(7), 771-788. https://doi.org/10.1016/j.jmoneco.2013.06.003

Bhagat, S., Bolton, B., \& Lu, J. (2015). Size, leverage, and risk-taking of financial institutions. Journal of Banking and Finance, 59, 520-537. https://doi.org/10.1016/j.jbankfin.2015.06.018

Black, L. K., Correa, R., Huang, X., \& Zhou, H. (2016). The systemic risk of European banks during the financial and sovereign debt crises. Journal of Banking \& Finance, 63, 107-125. https://doi.org/10.1016/j.jbankfin.2015.09.007

Bruno, V., Shim, I., \& Shin, H. S. (2017). Comparative assessment of macroprudential policies. Journal of Financial Stability, 28, 183-202. https://doi.org/10.1016/j.jfs.2016.04.001

Carbó-Valverde, S., Benink, H. A., Berglund, T., \& Wihlborg, C. (2015). Regulatory response to the financial crisis in Europe: recent developments (2010-2013). Journal of Financial Economic Policy, 7(1), 29-50. https:// doi.org/10.1108/JFEP-11-2014-0071

Chen, S., Hwang, T.-C., \& Liu, H.-H. (2012). Motivation of risk-taking behavior of banks in different countries: an international perspective. Banks and Bank Systems, 7(2), 116-128.

Chinn, M. D., \& Ito, H. (2006). What Matters for Financial Development? Capital Controls, Institutions, and Interactions". Journal of Development Economics, 81(1), 163-192.

Čihák, M., \& Schaeck, K. (2010). How well do aggregate prudential ratios identify banking system problems? Journal of Financial Stability, 6(3), 130-144. https://doi.org/10.1016/j.jfs.2010.03.001

De Moraes, C. O., Montes, G. C., \& Antunes, J. A. P. (2016). How does capital regulation react to monetary policy? New evidence on the risk-taking channel. Economic Modelling, 56, 177-186. https://doi.org/10.1016/j. econmod.2016.03.025

Delis, M. D., \& Kouretas, G. P. (2011). Interest rates and bank risk-taking. Journal of Banking and Finance, 35(4), 840-855. https://doi.org/10.1016/j.jbankfin.2010.09.032

Dell'Ariccia, G., Laeven, L., \& Marquez, R. (2014). Real interest rates, leverage, and bank risk-taking. Journal of Economic Theory, 149(1), 65-99. https://doi.org/10.1016/j.jet.2013.06.002

Distinguin, I., Roulet, C., \& Tarazi, A. (2013). Bank regulatory capital and liquidity: Evidence from US and European publicly traded banks. Journal of Banking and Finance, 37(9), 3295-3317. https://doi.org/10.1016/j. jbankfin.2013.04.027

Dong, Y., Firth, M., Hou, W., \& Yang, W. (2016). Evaluating the performance of Chinese commercial banks: A comparative analysis of different types of banks. European Journal of Operational Research, 252 (1), 280-295. https://doi.org/10.1016/j.ejor.2015.12.038 
Fahr, S., \& Fell, J. (2017). Macroprudential policy - closing the financial stability gap. Journal of Financial Regulation and Compliance, 25(4), 334-359. https://doi.org/10.1108/JFRC-03-2017-0037

Fiador, V. O. (2015). Monetary Policy and Economic Performance - Evidence from Selected African countries. University of Cape Town.

Fiador, V. O., \& Biekpe, N. (2015). Monetary policy and exchange market pressure- evidene from sub-Saharan Africa. Applied Economics, 47(37), 3921-3937. https://doi.org/10.1080/00036846.2015.1023937

Forssbæck, J. (2011). Ownership structure, market discipline, and banks' risk-taking incentives under deposit insurance. Journal of Banking and Finance, 35(10), 2666-2678. https://doi.org/10.1016/j.jbankfin.2011.02.024

García-Kuhnert, Y., Marchica, M. T., \& Mura, R. (2013). Shareholder diversification and bank risk-taking. Journal of Financial Intermediation, 24(4), 602-635. https://doi.org/10.1016/j.jfi.2015.03.001

Hamza, H., \& Saadaoui, Z. (2013). Investment deposits, risk-taking and capital decisions in Islamic banks. Studies in Economics and Finance, 30(3), 244-265. https://doi.org/10.1108/SEF-Feb-2012-0016

Haque, F., \& Shahid, R. (2016). Ownership, risk-taking and performance of banks in emerging economies: evidence from India. Journal of Financial Economic Policy, 8(3), 282-297. https://doi.org/http://dx.doi. org/10.1108/JFEP-09-2015-0054

Ioannidou, V., Ongena, S., \& Peydró, J. L. (2015). Monetary policy, risk-taking, and pricing: Evidence from a quasi-natural experiment. Review of Finance, 19(1), 95-144. https://doi.org/10.1093/rof/rfu035

Jiménez, G., Ongena, S., Peydro, J.-L., \& Saurina, J. (2014). Hazardous Times for Monetary Policy: What Do Twenty-Three Million Bank Loans Say About the Effects of Monetary Policy on Credit Risk-Taking? Econometrica, 82(2), 463-505. https://doi.org/10.3982/ecta10104

Jokipii, T., \& Milne, A. (2011). Bank capital buffer and risk adjustment decisions. Journal of Financial Stability, 7(3), 165-178. https://doi.org/10.1016/j.jfs.2010.02.002

Kar, A. K. (2012). Does capital and financing structure have any relevance to the performance of microfinance institutions? International Review of Applied Economics, 26(3), 329-348. https://doi.org/10.1080/02692 171.2011.580267

Kolapo, T. F., Ayeni, R. K., \& Oke, M. O. (2012). Credit risk and commercial banks' performance in Nigeria: A panel model approach. Australian Journal of Business and Management Research, 2(02), 31-38.

Kuranchie-Pong, L., Bokpin, G. A., \& Andoh, C. (2016). Empirical evidence on disclosure and risk-taking of banks in Ghana. Journal of Financial Regulation and Compliance, 24(2), 197-212. https://oi.org/10.1108/ JFRC-05-2015-0025

Laeven, L., Ratnovski, L., \& Tong, H. (2016). Bank size, capital, and systemic risk: Some international evidence. Journal of Banking and Finance, 69(1), S25-S34. https://doi.org/10.1016/j.jbankfin.2015.06.022

Laeven, L., \& Valencia, F. (2013). Systemic Banking Crises Database. IMF Economic Review, 61, 225-270. https:// doi.org/10.1057/imfer.2013.12

Luo, Y., Tanna, S., \& De Vita, G. (2016). Financial openness, risk and bank efficiency: Cross-country evidence. Journal of Financial Stability, 24, 132-148. https://doi.org/10.1016/j.jfs.2016.05.003

Maddaloni, A., \& Peydró, J.-L. (2011). Bank Risk-taking, Securitization, Supervision, and Low Interest Rates: Evidence from the Euro-area and the U.S. Lending Standards. Review of Financial Studies, 24(6), 2121-2165. https:// doi.org/10.1093/rfs/hhr015

Matemilola, B. T., Bany-Ariffin, A. N., \& Muhtar, F. E. (2015). The impact of monetary policy on bank lending rate in South Africa. Borsa Istanbul Review, 15(1), 53-59. https://doi.org/10.1016/j.bir.2014.09.003

Mensah, C. (2013). The Relationship between Loan Default and Repayment Schedule in Microfinance Institutions in Ghana: A Case Study of Sinapi Aba Trust. Research Journal of Finance and Accounting, 4(19), 165-176.

Ofoeda, I., Abor, J., \& Adjasi, C. (1999). The Impact of Capital-Based Regulation on Bank Risk-Taking. Journal of Financial Regulation and Compliance, 8(4), 317-352. https://doi.org/10.1006/jin.1999.0276

Özşuca, E. A., \& Akbostanci, E. (2016). An Empirical Analysis of the Risk-Taking Channel of Monetary Policy in Turkey. Emerging Markets Finance \& Trade, 52(3), 589-609. https://doi.org/10.1080/1540496X.2015.1047300 
Pathan, S. (2009). Strong boards, CEO power and bank risk-taking. Journal of Banking and Finance, 33(7), 1340-1350. https://doi.org/10.1016/j.jbankfin.2009.02.001

Rahman, M. M., Zheng, C., \& Ashraf, B. N. (2015). Bank Size, Risk-taking and Capital Regulation in Bangladesh. Eurasian Journal of Business and Economics, 8(15), 95-114. https://doi.org/10.17015/ejbe.2015.015.05

Salle, I., \& Seppecher, P. (2018). Stabilizing an unstable complex economy on the limitations of simple rules. Journal of Economic Dynamics and Control, 91, 289-317. https://doi.org/10.1016/j.jedc.2018.02.014

Sarkar, S., \& Sensarma, R. (2016). The relationship between competition and risk-taking behaviour of Indian banks. Journal of Financial Economic Policy, 8(1), 95-119. https://doi.org/10.1108/JFEP-05-2015-0030

Stolz, S., \& Wedow, M. (2011). Banks' regulatory capital buffer and the business cycle: Evidence for Germany. Journal of Financial Stability, 7(2), 98-110. https://doi.org/10.1016/j.jfs.2009.09.001

Tabak, B. M., Gomes, G. M. R., \& Da Silva Medeiros, M. (2014). The impact of market power at bank level in risk-taking: The Brazilian case. International Review of Financial Analysis, 40, 154-165. https://doi. org/10.1016/j.irfa.2015.05.014

Terraza, V. (2015). The Effect of Bank Size on Risk Ratios: Implications of Banks' Performance. Procedia Economics and Finance, 30, 903-909. https://doi.org/10.1016/S2212-5671(15)01340-4

Zaini Abd Karim, M., Chan, S.-G., \& Hassan, S. (2010). Bank Efficiency and Non-Performing Loans: Evidence from Malaysia and Singapore. Prague Economic Papers, 19(2), 118-132. https://doi.org/10.18267/j.pep.367

Zheng, C., Xu, T., \& Liang, W. (2012). The empirical research of banks' capital buffer and risk adjustment decision making: Evidence from China's banks. China Finance Review International, 2(2), 163-179. https://doi. org/10.1108/20441391211215833 
EJAE $2021 \diamond 18(1) \diamond 15-38$

ABOYADANA. G. \& MONETARY POLICY AND BANK RISK-TAKING IN SUB-SAHARA AFRICA

\section{Figures and Tables:}

Figure 1: Money Policy in Sub-Sahara Africa

Table 1: Variables

\begin{tabular}{|c|c|c|c|c|}
\hline Variable & Measu & nent & Expected Sign & Data Source \\
\hline $\begin{array}{l}\text { Credit Risk } \\
\text { (NPLR) }\end{array}$ & $\begin{array}{l}\text { Ratio of Non-Performing } \\
\text { Loans to Total Loans }\end{array}$ & $\ln \frac{N P L}{\text { Total loans }}$ & & BankScope \\
\hline $\begin{array}{l}\text { Credit Risk } \\
\text { (LLP) }\end{array}$ & $\begin{array}{l}\text { Ratio of loan loss reserves } \\
\text { to total loans }\end{array}$ & $\frac{\text { Loans Loss Reserve }}{\text { Total Assets }}$ & & BankScope \\
\hline $\begin{array}{l}\text { Capital } \\
(\mathrm{CAP})\end{array}$ & $\begin{array}{l}\text { Ratio of Shareholders' } \\
\text { equity to total Bank Assets }\end{array}$ & $\ln \frac{\text { Equity }}{\text { Total Assets }}$ & & BankScope \\
\hline $\begin{array}{l}\text { Liquidity } \\
\text { (LIQ) }\end{array}$ & $\begin{array}{l}\text { Ratio of liquid assets to } \\
\text { total deposits and short- } \\
\text { term borrowing }\end{array}$ & 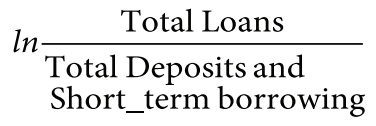 & & BankScope \\
\hline $\begin{array}{l}\text { Bank Size } \\
\text { (SIZE) }\end{array}$ & Natural log of Total Assets & $\ln ($ Total Assets $)$ & + & BankScope \\
\hline $\begin{array}{l}\text { Profitability } \\
\text { (ROAA) }\end{array}$ & $\begin{array}{l}\text { Ratio of Profit after tax to } \\
\text { Total assets }\end{array}$ & $\frac{\text { Profit after Tax }}{\text { Total Assets }}$ & - & BankScope \\
\hline $\begin{array}{l}\text { Cost Efficiency } \\
\text { (COSTEFF) }\end{array}$ & $\begin{array}{l}\text { Operating cost to Operating } \\
\text { income. }\end{array}$ & $\frac{\text { Total Expenses }}{\text { Total Revenue }}$ & - & BankScope \\
\hline $\begin{array}{l}\text { Monetary Policy } \\
(\mathrm{MPR})\end{array}$ & & & - & IMF \\
\hline $\begin{array}{l}\text { Competition } \\
(\mathrm{CR} 3)\end{array}$ & & & $\begin{array}{l}+ \\
-\end{array}$ & World Bank \\
\hline $\begin{array}{l}\text { Inflation Rate } \\
\text { (INF) }\end{array}$ & & & + & World Bank \\
\hline $\begin{array}{l}\text { GDP Growth } \\
\text { (GDP) }\end{array}$ & & & + & World Bank \\
\hline $\begin{array}{l}\text { Financial } \\
\text { Openness }\end{array}$ & & & - & $\begin{array}{l}\text { Chinn \& Ito } \\
\text { (2006) }\end{array}$ \\
\hline
\end{tabular}


Table 2: Summary Statistics

\begin{tabular}{lllll}
\hline Untransformed Variables & Mean & SD & Min & Max \\
\hline Inflation & 9.684 & 20.95 & -35.84 & 359.9 \\
\hline GDP Growth & 5.399 & 4.502 & -36.70 & 63.38 \\
\hline Competition & 69.73 & 18.97 & 23.32 & 100 \\
\hline Financial Openness & -0.348 & 1.436 & -1.895 & 2.389 \\
\hline Monetary Policy Rate & 10.81 & 7.435 & 2 & 70 \\
\hline Profitability & 1.201 & 6.247 & -160.1 & 78.37 \\
\hline Capitalization & 16.24 & 15.87 & -46.03 & 99.85 \\
\hline Cost Efficiency & 66.78 & 47.59 & 0.141 & 732.9 \\
\hline Size (Total Assets-USD) & 1210417 & 6578848 & 88.8754 & $124 \mathrm{e}+08$ \\
\hline LLP & 6.364 & 8.041 & 100 & -0.240 \\
\hline NPL & 8.45 & 10.94 & 0.008 & 100 \\
\hline Winsorized Variables & & & & \\
\hline Cost Efficiency & 61.98 & 19.31 & 35.47 & 98.09 \\
\hline Inflation & 7.647 & 4.832 & 1.298 & 16.19 \\
\hline Log transformed Variables & & & & 4.248 \\
\hline Monetary Policy Rate & 2.189 & 0.613 & 0.693 & 4.59 \\
\hline NPL & 7.672 & 1.757 & 0.693 & 11.59 \\
\hline Size & 12.15 & 1.659 & 4.487 & 18.64 \\
\hline Profitability & 0.571 & 0.989 & -6.908 & 4.361 \\
\hline Sores & & & & \\
\hline
\end{tabular}

Source: Research Data

Table 3: Correlation Matrix

\begin{tabular}{|c|c|c|c|c|c|c|c|c|c|c|}
\hline & 1 & 2 & 3 & 4 & 5 & 6 & 7 & 8 & 9 & 10 \\
\hline 1. Inflation & 1.00 & & & & & & & & & \\
\hline 2. GDP Growth & $-0.06^{*}$ & 1.00 & & & & & & & & \\
\hline 3. Competition & $0.07^{\star}$ & $-0.12^{*}$ & 1.00 & & & & & & & \\
\hline 4. Monetary Policy Rate & $0.48^{\star}$ & $0.08^{*}$ & $-0.03^{\star}$ & 1.00 & & & & & & \\
\hline 5. Profitability & -0.00 & 0.01 & 0.02 & -0.00 & 1.00 & & & & & \\
\hline 6. Cost Efficiency & 0.01 & -0.00 & 0.01 & $-0.06^{*}$ & $0.04^{*}$ & 1.00 & & & & \\
\hline 7. LLP & 0.01 & $0.03^{\star}$ & -0.03 & 0.01 & -0.01 & $-0.06^{*}$ & 1.00 & & & \\
\hline 8. Size & -0.01 & $-0.07^{\star}$ & $0.04^{*}$ & $-0.06^{*}$ & -0.00 & 0.02 & -0.01 & 1.00 & & \\
\hline 9. NPL & -0.02 & $-0.08^{*}$ & $0.07^{*}$ & -0.00 & -0.03 & 0.00 & 0.06 & -0.03 & 1.00 & \\
\hline 10. Financial Openness & $-0.03^{\star}$ & $-0.02^{*}$ & $-0.28^{\star}$ & $0.15^{\star}$ & 0.02 & 0.00 & 0.02 & $-0.07^{\star}$ & $-0.06^{*}$ & 1.00 \\
\hline
\end{tabular}

Source: Research Data 
Table 4: Breusch-Pagan / Cook-Weisberg test for heteroscedasticity

\begin{tabular}{lll}
\hline & Credit Risk & Asset Risk \\
\hline Chi2 $(1)$ & 12.1 & 134.01 \\
\hline Prob $>$ Chi2 & $0.0005^{* * *}$ & $0.0000^{* * *}$ \\
\hline
\end{tabular}

Source: Research Data

Table 5: Wooldridge test for autocorrelation

H0: No first order autocorrelation

\begin{tabular}{llll}
\hline & Df & F-Statistic & Prob $>$ F \\
\hline Credit Risk & F $(1,35)$ & 9.9111 & $0.0034^{* * *}$ \\
\hline Asset Risk & F $(1,51)$ & 18.665 & $0.0001^{* * *}$ \\
\hline
\end{tabular}

Source: Research Data

Table 6: Test of Endogeneity

H0: Variables are Exogenous

\begin{tabular}{lllll}
\hline Model & Durbin(score) Chi2(1) & Prob>Chi2 & Wu-Hausman F (v1, v2) & Prob $>$ F \\
\hline Credit Risk & $0.0820(1)$ & 0.7745 & $0.0793(1,262)$ & 0.7784 \\
\hline Asset Risk & $0.0402(1)$ & 0.8410 & $0.0393(1,376)$ & 0.8429 \\
\hline
\end{tabular}

Source: Research Data 
Table 7: Monetary Policy and Risk-taking (LSDV)

\begin{tabular}{|c|c|c|c|c|c|c|c|c|}
\hline & $(1)$ & $(2)$ & (3) & $(4)$ & $(5)$ & (6) & $(7)$ & $(8)$ \\
\hline Variables & NPL & NPL & NPL & NPL & NPL & NPL & NPL & NPL \\
\hline \multirow[t]{2}{*}{$\begin{array}{l}\text { Cost } \\
\text { Efficiency }\end{array}$} & $0.012^{\star * *}$ & $0.013^{* * *}$ & $0.013^{* * *}$ & $0.015^{\star * *}$ & $0.012^{* * *}$ & $0.013^{* * *}$ & $0.012^{* * *}$ & $0.014^{* * *}$ \\
\hline & $(0.004)$ & $(0.004)$ & $(0.004)$ & $(0.004)$ & $(0.004)$ & $(0.004)$ & $(0.004)$ & $(0.004)$ \\
\hline \multirow[t]{2}{*}{$\begin{array}{l}\text { Monetary } \\
\text { Policy }\end{array}$} & $1.409^{\star * *}$ & $1.186^{\star * *}$ & $1.036^{* * *}$ & $0.534^{\star * *}$ & $0.749^{\star *}$ & $0.549^{\star}$ & 0.379 & -0.070 \\
\hline & $(0.312)$ & $(0.260)$ & $(0.287)$ & $(0.174)$ & $(0.365)$ & $(0.320)$ & $(0.337)$ & $(0.247)$ \\
\hline \multirow[t]{2}{*}{$\begin{array}{l}\text { Monetary } \\
\text { Policyt-1 }\end{array}$} & & & & & $0.731^{\star * *}$ & $0.734^{\star * *}$ & $0.749^{* * *}$ & $0.759^{* * *}$ \\
\hline & & & & & $(0.248)$ & $(0.249)$ & $(0.248)$ & $(0.251)$ \\
\hline \multirow[t]{2}{*}{ MPRCAP } & -0.032 & & $-0.049^{* *}$ & & -0.028 & & $-0.042^{*}$ & \\
\hline & $(0.024)$ & & $(0.024)$ & & $(0.023)$ & & $(0.024)$ & \\
\hline \multirow[t]{2}{*}{ MPRLIQ } & $-0.014^{* * *}$ & $-0.017^{\star * *}$ & & & $-0.013^{* *}$ & $-0.016^{\star * *}$ & & \\
\hline & $(0.005)$ & $(0.005)$ & & & $(0.006)$ & $(0.006)$ & & \\
\hline \multirow[t]{2}{*}{$\begin{array}{l}\text { Financial } \\
\text { Openness }\end{array}$} & 0.015 & 0.024 & 0.027 & 0.047 & -0.031 & -0.023 & -0.019 & -0.002 \\
\hline & $(0.049)$ & $(0.048)$ & $(0.050)$ & $(0.049)$ & $(0.052)$ & $(0.051)$ & $(0.053)$ & $(0.053)$ \\
\hline \multirow[t]{2}{*}{ GDP Growth } & 0.009 & 0.015 & 0.016 & 0.027 & 0.002 & 0.006 & 0.007 & 0.017 \\
\hline & $(0.026)$ & $(0.025)$ & $(0.026)$ & $(0.025)$ & $(0.026)$ & $(0.025)$ & $(0.026)$ & $(0.026)$ \\
\hline \multirow[t]{2}{*}{ Inflation } & 0.008 & 0.009 & 0.001 & 0.000 & -0.006 & -0.005 & -0.013 & -0.013 \\
\hline & $(0.022)$ & $(0.022)$ & $(0.022)$ & $(0.022)$ & $(0.023)$ & $(0.023)$ & $(0.023)$ & $(0.023)$ \\
\hline \multirow[t]{2}{*}{ Competition } & $0.015^{\star * *}$ & $0.016^{\star * *}$ & $0.016^{* * *}$ & $0.018^{* * *}$ & $0.013^{* * *}$ & $0.013^{* * *}$ & $0.014^{* * *}$ & $0.015^{\star * *}$ \\
\hline & $(0.004)$ & $(0.004)$ & $(0.004)$ & $(0.004)$ & $(0.004)$ & $(0.004)$ & $(0.004)$ & $(0.004)$ \\
\hline \multirow[t]{2}{*}{ Profitability } & -0.167 & -0.177 & -0.197 & $-0.224^{*}$ & $-0.226^{*}$ & $-0.236^{*}$ & $-0.253^{\star}$ & $-0.277^{\star *}$ \\
\hline & $(0.130)$ & $(0.126)$ & $(0.131)$ & $(0.126)$ & $(0.134)$ & $(0.131)$ & $(0.134)$ & $(0.130)$ \\
\hline \multirow[t]{2}{*}{ Size } & $0.155^{\star \star *}$ & $0.184^{\star * *}$ & $0.198^{\star * *}$ & $0.260^{* * *}$ & $0.163^{\star * *}$ & $0.188^{\star * *}$ & $0.203^{\star * *}$ & $0.257^{\star * *}$ \\
\hline & $(0.043)$ & $(0.036)$ & $(0.041)$ & $(0.028)$ & $(0.044)$ & $(0.037)$ & $(0.041)$ & $(0.030)$ \\
\hline \multirow[t]{2}{*}{ CAP } & $0.093^{\star}$ & $0.021^{\star * *}$ & $0.132^{\star \star}$ & $0.023^{* * *}$ & 0.081 & $0.018^{\star * *}$ & $0.114^{\star *}$ & $0.020^{\star * *}$ \\
\hline & $(0.053)$ & $(0.006)$ & $(0.053)$ & $(0.006)$ & $(0.051)$ & $(0.006)$ & $(0.052)$ & $(0.006)$ \\
\hline \multirow[t]{2}{*}{ LIQ } & $0.035^{\star * *}$ & $0.040^{* * *}$ & $0.007^{\star *}$ & $0.007^{\star *}$ & $0.034^{* * *}$ & $0.039^{* * *}$ & $0.009^{* *}$ & $0.010^{* * *}$ \\
\hline & $(0.011)$ & $(0.011)$ & $(0.004)$ & $(0.004)$ & $(0.011)$ & $(0.011)$ & $(0.004)$ & $(0.004)$ \\
\hline Observations & 547 & 547 & 547 & 547 & 515 & 515 & 515 & 515 \\
\hline R-Squared & 0.948 & 0.948 & 0.948 & 0.947 & 0.949 & 0.949 & 0.948 & 0.948 \\
\hline
\end{tabular}

\section{Source: Research Data}

Robust standard errors in parentheses

$* * * p<0.01, * * p<0.05, * p<0.1$ 
Table 8: Monetary Policy and Risk-taking

\begin{tabular}{|c|c|c|c|c|c|c|c|c|}
\hline & (1) & (2) & (3) & (4) & (5) & (6) & (7) & (8) \\
\hline Variables & LLP & LLP & LLP & LLP & LLP & LLP & LLP & LLP \\
\hline \multirow[t]{2}{*}{$\begin{array}{l}\text { Cost } \\
\text { Efficiency }\end{array}$} & $0.050^{\star * *}$ & $0.050^{\star * *}$ & $0.057^{\star * *}$ & $0.056^{\star * *}$ & $0.051^{* * *}$ & $0.050^{\star * *}$ & $0.057^{* * *}$ & $0.057^{\star * *}$ \\
\hline & $(0.017)$ & $(0.017)$ & $(0.017)$ & $(0.017)$ & $(0.018)$ & $(0.018)$ & $(0.017)$ & $(0.017)$ \\
\hline \multirow[t]{2}{*}{$\begin{array}{l}\text { Monetary } \\
\text { Policy }\end{array}$} & $4.702^{\star \star \star}$ & $4.978^{\star \star \star}$ & $1.581^{\star *}$ & $1.643^{\star * *}$ & $5.036^{\star * *}$ & $5.326^{* * *}$ & 2.117 & $2.201^{\star}$ \\
\hline & $(0.980)$ & $(0.892)$ & $(0.798)$ & $(0.599)$ & (1.458) & (1.395) & $(1.328)$ & (1.234) \\
\hline \multirow[t]{2}{*}{$\begin{array}{l}\text { Monetary } \\
\text { Policyt-1 }\end{array}$} & & & & & -0.813 & -0.846 & -0.988 & -0.996 \\
\hline & & & & & $(1.261)$ & $(1.264)$ & $(1.291)$ & $(1.292)$ \\
\hline \multirow[t]{2}{*}{ MPRCAP } & 0.030 & & 0.006 & & 0.028 & & 0.007 & \\
\hline & $(0.039)$ & & $(0.045)$ & & $(0.038)$ & & $(0.043)$ & \\
\hline \multirow[t]{2}{*}{ MPRLIQ } & $-0.081^{\star * *}$ & $-0.080^{* * *}$ & & & $-0.078^{\star * *}$ & $-0.077^{\star * *}$ & & \\
\hline & $(0.015)$ & $(0.015)$ & & & $(0.016)$ & $(0.016)$ & & \\
\hline \multirow[t]{2}{*}{$\begin{array}{l}\text { Financial } \\
\text { Openness }\end{array}$} & -0.073 & -0.083 & -0.005 & -0.007 & 0.000 & -0.008 & 0.086 & 0.083 \\
\hline & $(0.229)$ & $(0.228)$ & $(0.232)$ & $(0.232)$ & $(0.226)$ & $(0.225)$ & $(0.229)$ & $(0.229)$ \\
\hline \multirow[t]{2}{*}{ GDP Growth } & -0.072 & -0.075 & -0.026 & -0.026 & -0.034 & -0.037 & 0.013 & 0.012 \\
\hline & $(0.078)$ & $(0.078)$ & $(0.078)$ & $(0.078)$ & $(0.082)$ & $(0.082)$ & $(0.082)$ & $(0.082)$ \\
\hline \multirow[t]{2}{*}{ Inflation } & -0.009 & -0.005 & -0.045 & -0.044 & -0.004 & 0.000 & -0.030 & -0.029 \\
\hline & $(0.078)$ & $(0.077)$ & $(0.080)$ & $(0.079)$ & $(0.079)$ & $(0.079)$ & $(0.082)$ & $(0.081)$ \\
\hline \multirow[t]{2}{*}{ Competition } & $-0.022^{*}$ & $-0.023^{\star}$ & -0.011 & -0.011 & -0.017 & -0.018 & -0.006 & -0.006 \\
\hline & $(0.013)$ & $(0.013)$ & $(0.013)$ & $(0.013)$ & $(0.013)$ & $(0.013)$ & $(0.013)$ & $(0.013)$ \\
\hline \multirow[t]{2}{*}{ Profitability } & 0.270 & 0.276 & 0.118 & 0.120 & 0.210 & 0.216 & 0.063 & 0.065 \\
\hline & $(0.327)$ & $(0.327)$ & $(0.332)$ & $(0.332)$ & $(0.334)$ & $(0.334)$ & $(0.340)$ & $(0.339)$ \\
\hline \multirow[t]{2}{*}{ Size } & -0.112 & -0.148 & $0.225^{\star *}$ & $0.217^{\star *}$ & -0.080 & -0.114 & $0.246^{* *}$ & $0.236^{* *}$ \\
\hline & $(0.121)$ & $(0.112)$ & $(0.110)$ & $(0.093)$ & $(0.124)$ & $(0.115)$ & $(0.110)$ & $(0.096)$ \\
\hline \multirow[t]{2}{*}{ CAP } & -0.092 & $-0.029^{*}$ & -0.034 & -0.022 & -0.086 & -0.027 & -0.036 & -0.021 \\
\hline & $(0.077)$ & $(0.017)$ & $(0.088)$ & $(0.017)$ & $(0.075)$ & $(0.017)$ & $(0.085)$ & $(0.017)$ \\
\hline \multirow[t]{2}{*}{ LIQ } & $0.092^{\star * *}$ & $0.090^{* * *}$ & $-0.050^{* * *}$ & $-0.050^{* * *}$ & $0.087^{\star * *}$ & $0.085^{\star \star \star}$ & $-0.048^{\star *}$ & $-0.048^{\star *}$ \\
\hline & $(0.029)$ & $(0.029)$ & $(0.019)$ & $(0.019)$ & $(0.030)$ & $(0.030)$ & $(0.020)$ & $(0.020)$ \\
\hline Observations & 704 & 704 & 704 & 704 & 671 & 671 & 671 & 671 \\
\hline R-Squared & 0.448 & 0.447 & 0.431 & 0.431 & 0.442 & 0.441 & 0.427 & 0.427 \\
\hline
\end{tabular}

\section{Source: Research Data}

Robust standard errors in parentheses

$* * * p<0.01, * * p<0.05, * p<0.1$ 
Table 9a: Countries without exchange controls

\begin{tabular}{|c|c|c|c|c|c|c|c|c|}
\hline & (1) & (2) & (3) & (4) & (5) & (6) & (7) & (8) \\
\hline Variables & NPL & NPL & NPL & NPL & NPL & NPL & NPL & NPL \\
\hline \multirow[t]{2}{*}{$\begin{array}{l}\text { Cost } \\
\text { Efficiency }\end{array}$} & $0.011^{* * *}$ & $0.013^{* * *}$ & $0.011^{* * *}$ & $0.014^{* * *}$ & $0.011^{* * *}$ & $0.012^{* * *}$ & $0.011^{* * *}$ & $0.013^{* * *}$ \\
\hline & $(0.004)$ & $(0.004)$ & $(0.004)$ & $(0.004)$ & $(0.004)$ & $(0.004)$ & $(0.004)$ & $(0.004)$ \\
\hline \multirow[t]{2}{*}{$\begin{array}{l}\text { Monetary } \\
\text { Policy }\end{array}$} & $1.502^{\star * *}$ & $1.256^{\star * *}$ & $1.383^{\star * *}$ & $0.877^{\star * *}$ & 0.588 & 0.368 & $0.547^{\star}$ & 0.120 \\
\hline & $(0.311)$ & $(0.274)$ & $(0.274)$ & $(0.170)$ & $(0.365)$ & $(0.336)$ & $(0.318)$ & $(0.242)$ \\
\hline \multirow[t]{2}{*}{$\begin{array}{l}\text { Monetary } \\
\text { Policyt-1 }\end{array}$} & & & & & $0.969^{\star * *}$ & $0.960^{\star * *}$ & $0.974^{* * *}$ & $0.981^{\star * *}$ \\
\hline & & & & & $(0.270)$ & $(0.271)$ & $(0.268)$ & $(0.271)$ \\
\hline \multirow[t]{2}{*}{ MPRCAP } & $-0.041^{\star}$ & & $-0.048^{\star *}$ & & $-0.037^{\star}$ & & $-0.039^{*}$ & \\
\hline & $(0.023)$ & & $(0.022)$ & & $(0.021)$ & & $(0.021)$ & \\
\hline \multirow[t]{2}{*}{ MPRLIQ } & -0.005 & $-0.011^{*}$ & & & -0.002 & -0.006 & & \\
\hline & $(0.006)$ & $(0.006)$ & & & $(0.006)$ & $(0.006)$ & & \\
\hline \multirow[t]{2}{*}{$\begin{array}{l}\text { Financial } \\
\text { Openness }\end{array}$} & $0.112^{\star *}$ & $0.119^{\star *}$ & $0.118^{\star *}$ & $0.137^{\star * *}$ & 0.067 & 0.073 & 0.069 & 0.084 \\
\hline & $(0.051)$ & $(0.051)$ & $(0.052)$ & $(0.051)$ & $(0.054)$ & $(0.054)$ & $(0.054)$ & $(0.054)$ \\
\hline \multirow[t]{2}{*}{ GDP Growth } & 0.019 & 0.026 & 0.022 & 0.035 & 0.019 & 0.026 & 0.020 & 0.031 \\
\hline & $(0.027)$ & $(0.026)$ & $(0.027)$ & $(0.026)$ & $(0.026)$ & $(0.025)$ & $(0.026)$ & $(0.025)$ \\
\hline \multirow[t]{2}{*}{ Inflation } & 0.038 & 0.038 & 0.037 & 0.037 & 0.024 & 0.024 & 0.023 & 0.023 \\
\hline & $(0.023)$ & $(0.023)$ & $(0.023)$ & $(0.024)$ & $(0.024)$ & $(0.024)$ & $(0.024)$ & $(0.024)$ \\
\hline \multirow[t]{2}{*}{ Competition } & $0.012^{\star * *}$ & $0.013^{\star * *}$ & $0.013^{\star * *}$ & $0.014^{\star * *}$ & $0.009^{*}$ & $0.009^{* *}$ & $0.009^{\star *}$ & $0.010^{* *}$ \\
\hline & $(0.004)$ & $(0.004)$ & $(0.004)$ & $(0.004)$ & $(0.004)$ & $(0.004)$ & $(0.004)$ & $(0.004)$ \\
\hline \multirow[t]{2}{*}{ Profitability } & $-0.380^{\star * *}$ & $-0.390^{\star * *}$ & $-0.388^{\star * *}$ & $-0.415^{\star * *}$ & $-0.451^{\star * *}$ & $-0.462^{\star * *}$ & $-0.454^{* * *}$ & $-0.477^{\star * *}$ \\
\hline & $(0.114)$ & $(0.111)$ & $(0.114)$ & $(0.110)$ & $(0.118)$ & $(0.115)$ & $(0.117)$ & $(0.113)$ \\
\hline \multirow[t]{2}{*}{ Size } & $0.105^{\star *}$ & $0.136^{\star * *}$ & $0.119^{\star * *}$ & $0.181^{\star * *}$ & $0.119^{\star * *}$ & $0.148^{\star * *}$ & $0.124^{\star \star \star}$ & $0.175^{\star * *}$ \\
\hline & $(0.043)$ & $(0.038)$ & $(0.040)$ & $(0.030)$ & $(0.044)$ & $(0.039)$ & $(0.041)$ & $(0.032)$ \\
\hline \multirow[t]{2}{*}{ CAP } & $0.116^{\star *}$ & $0.024^{\star * *}$ & $0.132^{\star * *}$ & $0.026^{* * *}$ & $0.104^{\star *}$ & $0.021^{\star * *}$ & $0.109^{\star *}$ & $0.022^{\star * *}$ \\
\hline & $(0.051)$ & $(0.006)$ & $(0.049)$ & $(0.006)$ & $(0.048)$ & $(0.006)$ & $(0.047)$ & $(0.006)$ \\
\hline \multirow[t]{2}{*}{ LIQ } & 0.019 & $0.031^{\star *}$ & $0.008^{\star *}$ & $0.009^{\star *}$ & 0.013 & $0.023^{*}$ & $0.010^{\star *}$ & $0.010^{\star * *}$ \\
\hline & $(0.013)$ & $(0.013)$ & $(0.004)$ & $(0.004)$ & $(0.013)$ & $(0.013)$ & $(0.004)$ & $(0.004)$ \\
\hline Observations & 444 & 444 & 444 & 444 & 414 & 414 & 414 & 414 \\
\hline R-squared & 0.954 & 0.953 & 0.953 & 0.953 & 0.955 & 0.954 & 0.955 & 0.954 \\
\hline
\end{tabular}

\section{Source: Research Data}

Robust standard errors in parentheses

$* * * p<0.01, * * p<0.05, * p<0.1$ 
Table 9b: Countries without exchange controls

\begin{tabular}{|c|c|c|c|c|c|c|c|c|}
\hline & (1) & (2) & (3) & $(4)$ & (5) & (6) & (7) & $(8)$ \\
\hline Variables & LLP & LLP & LLP & LLP & LLP & LLP & LLP & LLP \\
\hline \multirow[t]{2}{*}{$\begin{array}{l}\text { Cost } \\
\text { Efficiency }\end{array}$} & $0.040^{* *}$ & $0.039^{*}$ & $0.044^{* *}$ & $0.043^{\star *}$ & $0.040^{*}$ & $0.039^{*}$ & $0.044^{\star *}$ & $0.043^{\star *}$ \\
\hline & $(0.020)$ & $(0.020)$ & $(0.020)$ & $(0.020)$ & $(0.021)$ & $(0.021)$ & $(0.020)$ & $(0.020)$ \\
\hline \multirow{2}{*}{$\begin{array}{l}\text { Monetary } \\
\text { Policy }\end{array}$} & $4.306^{* * *}$ & $4.631^{\star * *}$ & $2.283^{\star *}$ & $2.460^{\star * *}$ & $4.175^{\star *}$ & $4.545^{\star *}$ & $2.148^{\star}$ & $2.393^{\star *}$ \\
\hline & $(1.125)$ & $(1.090)$ & $(0.891)$ & $(0.706)$ & $(1.961)$ & $(1.985)$ & $(1.292)$ & $(1.188)$ \\
\hline \multirow[t]{2}{*}{$\begin{array}{l}\text { Monetary } \\
\text { Policyt-1 }\end{array}$} & & & & & -0.397 & -0.429 & -0.325 & -0.343 \\
\hline & & & & & $(1.416)$ & $(1.425)$ & $(1.394)$ & $(1.396)$ \\
\hline \multirow[t]{2}{*}{ MPRCAP } & 0.040 & & 0.015 & & 0.041 & & 0.020 & \\
\hline & $(0.043)$ & & $(0.044)$ & & $(0.042)$ & & $(0.044)$ & \\
\hline \multirow[t]{2}{*}{ MPRLIQ } & $-0.063^{\star *}$ & $-0.059^{* *}$ & & & $-0.060^{\star *}$ & $-0.057^{\star}$ & & \\
\hline & $(0.027)$ & $(0.027)$ & & & $(0.031)$ & $(0.030)$ & & \\
\hline \multirow[t]{2}{*}{$\begin{array}{l}\text { Financial } \\
\text { Openness }\end{array}$} & 0.147 & 0.142 & 0.236 & 0.232 & 0.216 & 0.212 & 0.313 & 0.307 \\
\hline & $(0.264)$ & $(0.264)$ & $(0.246)$ & $(0.246)$ & $(0.265)$ & $(0.265)$ & $(0.243)$ & $(0.243)$ \\
\hline \multirow[t]{2}{*}{ GDP Growth } & -0.059 & -0.063 & -0.008 & -0.011 & -0.016 & -0.020 & 0.031 & 0.027 \\
\hline & $(0.090)$ & $(0.090)$ & $(0.093)$ & $(0.093)$ & $(0.094)$ & $(0.094)$ & $(0.099)$ & $(0.099)$ \\
\hline \multirow[t]{2}{*}{ Inflation } & 0.049 & 0.056 & 0.054 & 0.057 & 0.047 & 0.056 & 0.056 & 0.060 \\
\hline & $(0.091)$ & $(0.089)$ & $(0.092)$ & $(0.091)$ & $(0.094)$ & $(0.092)$ & $(0.095)$ & $(0.093)$ \\
\hline \multirow[t]{2}{*}{ Competition } & -0.026 & -0.027 & -0.018 & -0.019 & -0.018 & -0.020 & -0.012 & -0.012 \\
\hline & $(0.017)$ & $(0.017)$ & $(0.017)$ & $(0.017)$ & $(0.016)$ & $(0.016)$ & $(0.017)$ & $(0.017)$ \\
\hline \multirow[t]{2}{*}{ Profitability } & 0.421 & 0.432 & 0.357 & 0.364 & 0.343 & 0.357 & 0.274 & 0.283 \\
\hline & $(0.418)$ & $(0.420)$ & $(0.404)$ & $(0.404)$ & $(0.436)$ & $(0.438)$ & $(0.416)$ & $(0.416)$ \\
\hline \multirow[t]{2}{*}{ Size } & -0.110 & -0.156 & 0.112 & 0.088 & -0.070 & -0.119 & 0.141 & 0.111 \\
\hline & $(0.153)$ & $(0.149)$ & $(0.135)$ & $(0.119)$ & $(0.158)$ & $(0.154)$ & $(0.142)$ & $(0.127)$ \\
\hline \multirow[t]{2}{*}{ CAP } & -0.108 & -0.022 & -0.044 & -0.011 & -0.111 & -0.021 & -0.054 & -0.011 \\
\hline & $(0.088)$ & $(0.019)$ & $(0.088)$ & $(0.018)$ & $(0.086)$ & $(0.018)$ & $(0.087)$ & $(0.018)$ \\
\hline \multirow[t]{2}{*}{ LIQ } & 0.061 & 0.053 & $-0.069^{\star * *}$ & $-0.069^{\star * *}$ & 0.057 & 0.048 & $-0.067^{\star *}$ & $-0.067^{\star *}$ \\
\hline & $(0.072)$ & $(0.070)$ & $(0.027)$ & $(0.026)$ & $(0.081)$ & $(0.079)$ & $(0.029)$ & $(0.029)$ \\
\hline Observations & 494 & 494 & 494 & 494 & 466 & 466 & 466 & 466 \\
\hline R-squared & 0.429 & 0.428 & 0.422 & 0.422 & 0.419 & 0.418 & 0.413 & 0.413 \\
\hline
\end{tabular}

\section{Source: Research Data}

Robust standard errors in parentheses

$* * * p<0.01, * * p<0.05, * p<0.1$ 
Table 10a: Countries with exchange controls

\begin{tabular}{|c|c|c|c|c|c|c|c|c|}
\hline & (1) & (2) & (3) & (4) & (5) & (6) & (7) & (8) \\
\hline Variables & NPL & NPL & NPL & NPL & NPL & NPL & NPL & NPL \\
\hline \multirow[t]{2}{*}{$\begin{array}{l}\text { Cost } \\
\text { Efficiency }\end{array}$} & 0.005 & 0.004 & 0.005 & 0.004 & 0.003 & 0.002 & 0.002 & 0.002 \\
\hline & $(0.009)$ & $(0.009)$ & $(0.010)$ & $(0.009)$ & $(0.010)$ & $(0.010)$ & $(0.010)$ & $(0.010)$ \\
\hline \multirow[t]{2}{*}{$\begin{array}{l}\text { Monetary } \\
\text { Policy }\end{array}$} & -0.020 & -1.752 & 0.823 & -1.117 & -4.193 & -5.998 & -0.268 & -1.354 \\
\hline & $(4.662)$ & $(4.665)$ & $(2.864)$ & $(0.935)$ & $(5.395)$ & $(4.753)$ & $(4.284)$ & $(2.888)$ \\
\hline \multirow[t]{2}{*}{$\begin{array}{l}\text { Monetary } \\
\text { Policyt-1 }\end{array}$} & & & & & 0.013 & 0.170 & 0.152 & 0.226 \\
\hline & & & & & $(2.735)$ & $(2.672)$ & $(2.768)$ & $(2.725)$ \\
\hline \multirow[t]{2}{*}{ MPRCAP } & -0.255 & & -0.228 & & -0.245 & & -0.119 & \\
\hline & $(0.350)$ & & $(0.320)$ & & $(0.350)$ & & $(0.324)$ & \\
\hline \multirow[t]{2}{*}{ MPRLIQ } & 0.019 & 0.011 & & & 0.092 & 0.084 & & \\
\hline & $(0.088)$ & $(0.084)$ & & & $(0.073)$ & $(0.073)$ & & \\
\hline \multirow[t]{2}{*}{$\begin{array}{l}\text { Financial } \\
\text { Openness }\end{array}$} & -6.153 & -8.472 & -5.072 & $-7.652^{\star *}$ & $-12.435^{\star *}$ & $-14.592^{\star \star}$ & -7.047 & $-8.376^{\star * *}$ \\
\hline & $(6.745)$ & $(6.876)$ & $(4.382)$ & $(2.956)$ & $(6.014)$ & $(5.622)$ & $(4.370)$ & $(2.801)$ \\
\hline \multirow[t]{2}{*}{ GDP Growth } & -0.049 & -0.045 & -0.049 & -0.046 & $-0.142^{*}$ & $-0.143^{*}$ & $-0.133^{*}$ & $-0.134^{*}$ \\
\hline & $(0.080)$ & $(0.080)$ & $(0.079)$ & $(0.080)$ & $(0.077)$ & $(0.076)$ & $(0.076)$ & $(0.076)$ \\
\hline \multirow[t]{2}{*}{ Inflation } & 0.027 & 0.021 & 0.024 & 0.020 & 0.043 & 0.040 & 0.031 & 0.030 \\
\hline & $(0.075)$ & $(0.074)$ & $(0.073)$ & $(0.072)$ & $(0.086)$ & $(0.086)$ & $(0.083)$ & $(0.083)$ \\
\hline \multirow[t]{2}{*}{ Competition } & -0.002 & -0.001 & -0.002 & -0.001 & -0.001 & 0.000 & 0.001 & 0.002 \\
\hline & $(0.012)$ & $(0.012)$ & $(0.012)$ & $(0.012)$ & $(0.012)$ & $(0.012)$ & $(0.012)$ & $(0.012)$ \\
\hline \multirow[t]{2}{*}{ Profitability } & $0.848^{\star *}$ & $0.841^{\star *}$ & $0.854^{* *}$ & $0.845^{\star *}$ & $0.830^{\star *}$ & $0.832^{\star *}$ & $0.865^{\star *}$ & $0.865^{\star *}$ \\
\hline & $(0.352)$ & $(0.350)$ & $(0.358)$ & $(0.354)$ & $(0.336)$ & $(0.334)$ & $(0.373)$ & $(0.370)$ \\
\hline \multirow[t]{2}{*}{ Size } & -0.053 & -0.091 & -0.049 & -0.086 & -0.151 & -0.182 & -0.118 & -0.135 \\
\hline & $(0.208)$ & $(0.210)$ & $(0.201)$ & $(0.200)$ & $(0.192)$ & $(0.190)$ & $(0.190)$ & $(0.186)$ \\
\hline \multirow[t]{2}{*}{ CAP } & 0.374 & 0.022 & 0.336 & 0.022 & 0.347 & 0.009 & 0.172 & 0.008 \\
\hline & $(0.480)$ & $(0.055)$ & $(0.441)$ & $(0.055)$ & $(0.483)$ & $(0.056)$ & $(0.449)$ & $(0.052)$ \\
\hline \multirow[t]{2}{*}{ LIQ } & -0.015 & -0.004 & 0.012 & 0.012 & -0.114 & -0.102 & $0.016^{\star}$ & $0.017^{\star}$ \\
\hline & $(0.122)$ & $(0.117)$ & $(0.009)$ & $(0.009)$ & $(0.102)$ & $(0.101)$ & $(0.009)$ & $(0.008)$ \\
\hline Observations & 103 & 103 & 103 & 103 & 101 & 101 & 101 & 101 \\
\hline R-squared & 0.955 & 0.955 & 0.955 & 0.955 & 0.960 & 0.960 & 0.959 & 0.959 \\
\hline
\end{tabular}

\section{Source: Research Data}

Robust standard errors in parentheses

$* * * p<0.01, * * p<0.05, * p<0.1$ 
Table 10b: Countries with exchange controls

\begin{tabular}{|c|c|c|c|c|c|c|c|c|}
\hline & (1) & (2) & (3) & (4) & (5) & (6) & (7) & (8) \\
\hline Variables & LLP & LLP & LLP & LLP & LLP & LLP & LLP & LLP \\
\hline \multirow[t]{2}{*}{$\begin{array}{l}\text { Cost } \\
\text { Efficiency }\end{array}$} & $0.067^{\star}$ & $0.067^{\star}$ & 0.056 & 0.056 & $0.068^{*}$ & $0.068^{*}$ & 0.060 & 0.060 \\
\hline & $(0.035)$ & $(0.035)$ & $(0.035)$ & $(0.035)$ & $(0.036)$ & $(0.036)$ & $(0.037)$ & $(0.036)$ \\
\hline \multirow[t]{2}{*}{$\begin{array}{l}\text { Monetary } \\
\text { Policy }\end{array}$} & $-14.063^{\star *}$ & $-15.987^{\star * *}$ & 1.200 & 1.011 & -12.215 & $-14.909^{\star}$ & 8.832 & 6.621 \\
\hline & (6.333) & (5.058) & $(4.685)$ & (1.773) & $(10.249)$ & $(8.367)$ & (8.359) & $(5.834)$ \\
\hline \multirow[t]{2}{*}{$\begin{array}{l}\text { Monetary } \\
\text { Policyt-1 }\end{array}$} & & & & & -2.442 & -2.319 & -5.706 & -5.592 \\
\hline & & & & & $(5.539)$ & $(5.499)$ & $(5.513)$ & $(5.448)$ \\
\hline \multirow[t]{2}{*}{ MPRCAP } & -0.253 & & -0.021 & & -0.308 & & -0.239 & \\
\hline & $(0.495)$ & & $(0.513)$ & & $(0.516)$ & & $(0.535)$ & \\
\hline \multirow[t]{2}{*}{ MPRLIQ } & $0.323^{* * *}$ & $0.317^{* * *}$ & & & $0.350^{* * *}$ & $0.348^{* * *}$ & & \\
\hline & $(0.089)$ & $(0.089)$ & & & $(0.101)$ & $(0.101)$ & & \\
\hline \multirow[t]{2}{*}{$\begin{array}{l}\text { Financial } \\
\text { Openness }\end{array}$} & $-45.749^{* * *}$ & $-48.138^{\star \star \star}$ & $-27.124^{\star * *}$ & $-27.358^{\star \star \star}$ & $-46.444^{\star * *}$ & $-49.591^{\star \star \star}$ & $-24.937^{\star \star \star}$ & $-27.503^{\star * *}$ \\
\hline & (9.249) & $(8.116)$ & (7.507) & (5.905) & (10.068) & $(8.407)$ & $(7.573)$ & $(6.014)$ \\
\hline \multirow[t]{2}{*}{ GDP Growth } & -0.127 & -0.126 & -0.122 & -0.122 & -0.123 & -0.124 & -0.092 & -0.092 \\
\hline & $(0.119)$ & $(0.118)$ & $(0.124)$ & $(0.123)$ & $(0.129)$ & $(0.130)$ & $(0.131)$ & $(0.131)$ \\
\hline \multirow[t]{2}{*}{ Inflation } & 0.232 & 0.231 & 0.218 & 0.218 & 0.206 & 0.206 & 0.154 & 0.154 \\
\hline & $(0.219)$ & $(0.218)$ & $(0.226)$ & $(0.225)$ & $(0.246)$ & $(0.246)$ & $(0.251)$ & $(0.251)$ \\
\hline \multirow[t]{2}{*}{ Competition } & $-0.104^{\star * *}$ & $-0.105^{\star * *}$ & $-0.109^{* * *}$ & $-0.109^{\star * *}$ & $-0.103^{\star * *}$ & $-0.103^{\star * *}$ & $-0.109^{\star * *}$ & $-0.108^{* * *}$ \\
\hline & $(0.021)$ & $(0.021)$ & $(0.022)$ & $(0.022)$ & $(0.021)$ & $(0.021)$ & $(0.022)$ & $(0.022)$ \\
\hline \multirow[t]{2}{*}{ Profitability } & 0.462 & 0.465 & 0.368 & 0.368 & 0.386 & 0.393 & 0.267 & 0.273 \\
\hline & $(0.440)$ & $(0.438)$ & $(0.459)$ & $(0.459)$ & $(0.415)$ & $(0.414)$ & $(0.454)$ & $(0.453)$ \\
\hline \multirow[t]{2}{*}{ Size } & $-1.763^{\star * \star}$ & $-1.772^{\star * *}$ & $-1.702^{\star * *}$ & $-1.703^{\star * *}$ & $-1.766^{\star * *}$ & $-1.776^{* * *}$ & $-1.693^{\star * *}$ & $-1.701^{\star * *}$ \\
\hline & $(0.342)$ & $(0.339)$ & $(0.341)$ & $(0.341)$ & $(0.346)$ & $(0.343)$ & $(0.348)$ & $(0.348)$ \\
\hline \multirow[t]{2}{*}{ CAP } & 0.349 & -0.009 & 0.015 & -0.015 & 0.430 & -0.005 & 0.329 & -0.009 \\
\hline & $(0.654)$ & $(0.106)$ & $(0.676)$ & $(0.108)$ & $(0.682)$ & $(0.107)$ & $(0.707)$ & $(0.109)$ \\
\hline \multirow[t]{2}{*}{ LIQ } & $-0.515^{\star * *}$ & $-0.506^{* * *}$ & $-0.041^{\star}$ & $-0.041^{\star}$ & $-0.552^{\star * *}$ & $-0.548^{\star * *}$ & $-0.046^{\star}$ & $-0.045^{\star}$ \\
\hline & $(0.139)$ & $(0.139)$ & $(0.023)$ & $(0.023)$ & $(0.152)$ & $(0.153)$ & $(0.025)$ & $(0.025)$ \\
\hline Observations & 210 & 210 & 210 & 210 & 205 & 205 & 205 & 205 \\
\hline R-squared & 0.610 & 0.610 & 0.592 & 0.592 & 0.613 & 0.612 & 0.597 & 0.597 \\
\hline
\end{tabular}

\section{Source: Research Data}

Robust standard errors in parentheses

$* * * p<0.01, * * p<0.05, * p<0.1$ 


\section{MONETARNA POLITIKA I PREUZIMANJE RIZIKA OD BANAKA U PODSAHARSKOJ AFRICI}

\section{Rezime:}

Pokazalo se da monetarna politika utiče na ponašanje preuzimanja rizika banaka u Evropi i Severnoj Americi. Međutim, Afrika dobija malo pažnje po ovom pitanju. Ovo istraživanje doprinosi monetarnoj politici i literaturi o preuzimanju rizika za podsaharsku Afriku ispitivanjem panela komercijalnih banaka od 2001. do 2015. godine za različite vrste rizika. Otkrivamo da monetarna politika značajno utiče na preuzimanje rizika banaka kako statistički, tako i ekonomski, ali se efekat razlikuje u zavisnosti od vrste rizika. Veličina banke i profitabilnost su važni za određivanje koliko efektivna monetarna politika utiče na preuzimanje rizika. Efekti su jači za zemlje bez kontrole deviznog kursa. Kada je reč o politici, monetarne vlasti koje nameravaju da vode ekspanzivnu monetarnu politiku moraju da poprave odgovor banaka na preuzimanje rizika.

Ključne reči:

preuzimanje rizika, finansijska kriza, monetarna politika, Afrika.

Klasifikacija jela:

E52, E58, G01, G18, G21, G28, G31 